\title{
Seed Pretreatments and Their Effects on Field Establishment of Spring-Seeded Gard- ner Saltbush
}

\author{
R. JAMES ANSLEY AND ROLLIN H. ABERNETHY
}

\begin{abstract}
Gardner saltbush [Atriplex gardneri (Moq.) D. Dietr.] seeds collected from the Red Desert Basin of Wyoming were subjected to pretreatments of scarification (Sc), washing (W), and stratification (St) to alleviate dormancy. Laboratory germination was evaluated. Subsequently, seedling vigor was observed by determining field emergence of similarly pretreated seeds spring planted at 1 irrigated and 2 dryland sites in Wyoming. Effects of $1-\mathrm{cm}$ and $3-\mathrm{cm}$ planting depths on emergence were also evaluated.

Seed was pretreated, then dehydrated with minimal impact on seed germination. Field emergence was much less than laboratory germination for all treatments at all sites, indicating that establishment for this species is related to poor seedling vigor as much as to seed dormancy. Moreover, when compared to untreated controls, relative responses to seed pretreatments often differed between laboratory and field trials. In the laboratory $S c=W=S t$ provided the greatest germination, whereas the best seed pretreatment for field establishment was Sc + St. Washing had little effect on enhancing field emergence and appeared to inhibit effects of $S t$ in scarified seed. The most effective planting depth varied with climatic/edaphic severity of the site.
\end{abstract}

Gardner saltbush (Atriplex gardneri (Moq.) D. Dietr.) is a low growing half-shrub (20-50 cm high) which occurs in cold desert

\footnotetext{
Authors are graduate assistant and assistant professor, Plant Science Division, University of Wyoming, Laramie 82071 . Senior author is currently located at Texas Agricultural Experiment Station, Vernon 76384

This article is Wyoming Agricultrual Experiment Station Journal Article No. JA-1264.

Research was supported by funds from the University of Wyoming Agricultural Experiment Station and the High Plains Grassland Research Station, through USDA-ARS Coop. Agreement No. 58-9AHZ-9-467.

Manuscript accepted December 13, 1983
}

regions of the Intermountain West. It is particularly adapted to saline, alkaline, and clay soil conditions, extreme temperatures and aridity (Stubbendieck et al. 1981). It has use on rangeland and disturbed lands because it is a soil stabilizer and provides valuable winter browse.

Direct seeding of Gardner saltbush and other native arid land shrub species on disturbed lands has often met with limited success (Bleak et al. 1965, Nord et al. 1971, Sindelar et al. 1974, Plummer 1976, McKell 1979, DePuit and Coenenberg 1980). Reasons for this can be attributed to seed related factors including low purity seed sources, low viability, seed dormancy, and poor seedling vigor, in addition to inimical environmental conditions.

Much recent research has contributed to the understanding of dormancy and germination requirements of native arid land shrub seeds (McDonough 1970, Wood et al. 1976, Eddleman 1978, Sabo et al. 1979, Young et al. 1980, Young et al. 1981, Young and Evans 1981), including Gardner saltbush (Foiles 1974, Eddleman 1978, Ansley 1983). Most of this research has been restricted to laboratory germination studies. These studies are necessary because establishment of a species from direct seeding would be impossible if seed dormancy was not first broken. However, an equally important area of research involves post-germination events, including seedling emergence from soil and subsequent survival under natural conditions. As Osmond et al. (1980) stated: ". . . it is the establishment phase rather than germination which is more vulnerable under natural conditions, and if this is so, the detailed physiology and biochemistry of germination is of somewhat academic interest."

Spring seeding is recommended for Gardner saltbush (Eddle- 
man 1978, Vories 1981). However, this species has a substantial stratification requirement (Ansley and Abernethy 1982). Young and Evans (1981) noted that once seeds of most species are stratified they must be planted immediately in a hydrated state for the germination enhancement to be effective and to retain viability. Seeding hydrated seeds is impractical for a variety of reasons. Therefore, fall seeding of species with a stratification requirement is the common practice on revegetation sites. However, problems encountered with fall seeding include seed loss from runoff, environmental exposure, loss of viability through time, fall emergence, and rodent predation.

Little is known regarding seedling vigor in Gardner saltbush. Seeding failures have been attributed to poor seedling vigor in some studies but the distinction between germination failure and events relating to post-germination emergence from soil (i.e. seedling vigor) was not made (McLean 1953, Nord et al. 1971).

The first objective of this study was to determine if artificially stratified seeds could be dehydrated immediately after treatment and subsequently spring planted without adversely affecting emergence.

The second objective of this study was to characterize seedling vigor in Gardner saltbush by (a) comparing laboratory blotter germination and field emergence of seed pretreated to alleviate dormancy and (b) determining effects of planting depth on field emergence. Post-germination emergence from the soil and first establishment were considered in this study to reflect "seedling vigor."

\section{Methods and Materials}

\section{Seed Procurement}

All seeds used in this study were collected within a 4-ha area 10 $\mathrm{km}$ west of Wamsutter in South Central Wyoming on August 4, 1981. The elevation and average annual precipitation are $2,100 \mathrm{~m}$ and $15-18 \mathrm{~cm}$, respectively. Average mean monthly temperatures range from $-2^{\circ} \mathrm{C}$ to $20^{\circ} \mathrm{C}$ with extremes ranging from $-39^{\circ} \mathrm{C}$ in January to $41^{\circ} \mathrm{C}$ in July (Becker and Alyea 1964). Vegetation at the site consists of predominantly Gardner saltbush interspersed with bud sagebrush (Artemisia spinescens D.C. Eaton), bottlebrush squirreltail (Sitanion hystrix Nutt.), and indian ricegrass (Oryzopsis hymenoides Roem. \& Schult.).

Seeds were collected by hand stripping the flower stalks (Eddleman 1978). Freshly harvested seeds were spread on a canvas tarp to air dry (Young et al. 1978). Impurities were removed via screening and by a "Dakota" adjustable plexiglass column blower (Young et al. 1978). Seeds were stored in paper bags at $20-24^{\circ} \mathrm{C}$ (Springfield 1970, Foiles 1974).

\section{Seed Fill and Viability}

The female Gardner saltbush flower has no perianth, protection being provided by 2 bracteoles 3-6 $\mathrm{mm}$ long which form a false fruit or utricle (Young et al. 1980). In our study the utricle was considered the "seed"(Nord et al. 1971, Young et al. 1980). Seed fill was determined by slicing 15 replicates of 100 utricles with a razor blade. Viability was determined by soaking embryos bisected during the seed fill test in a $0.1 \%$ 2,3,5-triphenyl-2H-tetrazolium chloride (TZ) solution for 4-8 hours (Grabe 1970, Weber and Wiesner 1980). Five replicates, each containing 25 embryos, were used for the TZ test.

\section{Seed Pretreatments}

Seed pretreatments used in this study were previously determined to provide varying levels of increase in laboratory blotter germination and included: scarification (Sc), washing (W), and cold stratification (St), arranged in all combinations. Seeds occupying a volume of $250 \mathrm{~cm}^{3}$ were scarified for 20 seconds in a Forsberg scarifier' at 1,725 RPM. Washing was conducted in flowing tap water (flow rate: $35-40 \mathrm{ml}$ per sec; $6^{\circ} \mathrm{C}$ ) for 24 hours. Washed seeds were then air dried $\left(21^{\circ} \mathrm{C}\right)$ for 24 hours. Stratification involved maintaining imbibed seeds at $2^{\circ} \mathrm{C}$ for 3 weeks. For combination treatments (i.e. $\mathbf{S c}+\mathbf{W}, \mathbf{S c}+\mathrm{St}, \mathrm{W}+\mathrm{St}$ and $\mathbf{S c}+\mathrm{W}+\mathrm{St}$ ), seeds were initially scarified, then washed, air dried 24 hours, and finally rehydrated and stratified. Nontreated controls were included for all comparisons.

To determine oven-dry weight loss due to the scarification treatment, fresh seeds were weighed, scarified, oven dried at $100^{\circ} \mathrm{C}$ for 24 hours, and reweighed. These were then compared on an oven dry weight per seed basis to a set of unscarified seeds which had been weighed, oven dried, and reweighed. To determine oven dry weight loss from the wash treatment, scarified and unscarified seeds were weighed while in the fresh condition, then enclosed in cheesecloth and exposed to running tap water 24 hours. Following washing, seeds were removed from the cheesecloth, oven dried, and again weighed.

\section{Laboratory Germination}

Pretreated 8 month post-harvest seeds were germinated from April to May, 1982 , in a germinator cycled at $24^{\circ} \mathrm{C}$-light $(16$ hours) $/ 13^{\circ} \mathrm{C}$-dark ( 8 hours). Each treatment was replicated 6 times. Each replication consisted of a $10 \times 10 \times 2.5-\mathrm{cm}$ plastic box and tightly fitting lid containing 100 seeds on one sheet heavy blotter with an initial application of $10 \mathrm{ml}$ distilled water. Germination, as indicated by $15-\mathrm{mm}$ radicle extension, was assessed at 5 -day intervals for 35 days.

\section{Field Emergence}

Concurrent with the laboratory studies, seeds were similarly pretreated and spring planted at 2 seeding depths and at 3 different sites in Wyoming:

(1) on April 7 at a topsoiled coal mine reclamation site operated by Bridger Coal Co., $30 \mathrm{~km}$ west of Wamsutter,

(2) on April 28 at a topsoiled bentonite mine reclamation site operated by Wyo-Ben Inc., $12 \mathrm{~km}$ east of Thermopolis, and (3) on June 9 at University of Wyoming research plots in Laramie.

Treatments were arranged in a split-plot design with seed planting depths as main plots and seed pretreatments (i.e. Sc, W, St) arranged in a completely randomized $2 \times 2 \times 2$ factorial as subplots. Wash and stratification treatments were conducted in the laboratory and seeds were air dired at $21-24^{\circ} \mathrm{C}$ for 16 to 24 hours prior to seeding. Effects of various periods of air drying at $21^{\circ} \mathrm{C}$ following 24 hour wash and 3 week stratification treatments on Gardner saltbush germination on blotter paper were concurrently observed. A single row cone seeder with a knife furrow opener was used for seeding. Two seeding depths, $1 \mathrm{~cm}$ and $3 \mathrm{~cm}$, were evaluated.

Each treatment replication consisted of 350 seeds planted in a single row $6.4 \mathrm{~m}$ long. Treatments were replicated 4 times at Bridger, 8 at Thermopolis, and 5 at Laramie. Replication number was dependent on the size constraints of each site. Seedlings were counted periodically at each site from June to September, 1982. Seedlings were considered emerged when the first pair of (noncotyledon) leaves were observed.

The reclamation sites were seeded in April to take advantage of soil moisture accumulated during winter. The sites were not irrigated after seeding. The Thermopolis site was fenced to exclude sheep and deer, which are prevalent in the area. The Bridger site was unfenced. It was assumed mining activity less than $300 \mathrm{~m}$ from the research site would preclude large herbivores from grazing on the site. Rodents and other small herbivores as well as weeds were not controlled at either of the reclamation sites.

To observe seedling emergence under conditions which might be considered least-limiting, the Laramie site was seeded later in the spring on June 9 to avoid colder soil temperatures. One centimeter of water was sprinkler applied every 5 days for the first 30 days after seeding. Large herbivores, rodents, and weeds were excluded.

Data from laboratory and field studies were subjected to analysis of variance procedures. Duncan's multiple range test or the $\operatorname{LSD}(P \leq 0.05)$ was used to test differences between means. 


\section{Results and Discussion}

\section{Seed Fill and Viability}

Average seed fill was $48 \%$. Viability was difficult to determine using the TZ test. Some staining occurred on $94 \%$ of the embryos tested, which would suggest a maximum pure live seed (PLS) of $(.94 \times .48) 45 \%$. However, in most of those embryos, staining was nonuniform with portions (i.e., radicle, hypotocyl, cotyledons) being either dark red, pink, or unstained. Blotter germination tests conducted 17 months post-harvest on this seed source provide $90 \%$ germination of filled seed or (90/94) 96\% of PLS (Ansley 1983). Therefore it was assumed that embryos with some staining were viable. Only those embryos with no staining were classified as nonviable.

Weber and Wiesner (1980) noted it is often difficult to achieve adequate $T Z$ staining in embryos of many native forbs and shrubs. Further research is needed to more accurately evaluate TZ embryo staining in Gardner saltbush.

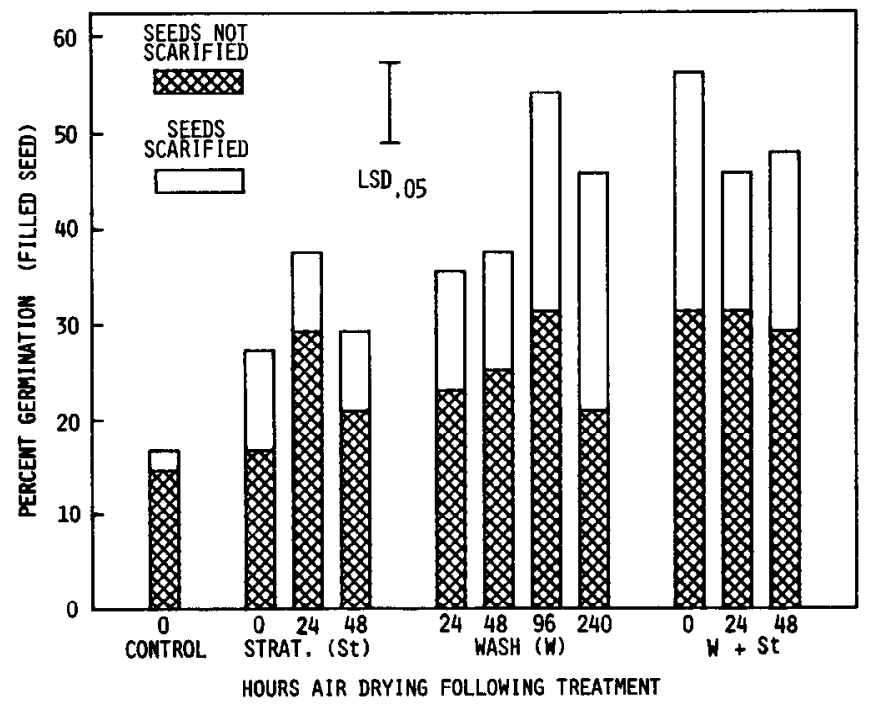

Fig. 1. Effects of various drying periods $\left(21^{\circ} \mathrm{C}\right)$ following 3 weeks stratification (St), 24 hours washing $(W)$, and stratification + washing $(S t+W)$ on blotter germination of unscarified and scarified 8 months post-harvest Gardner saltbush seeds.

Effects of Air Drying Following Wash and Stratification

Results indicated that up to 48 hours air drying did not adversely affect germination enhancement from stratification (St) and stratification + washing $(\mathrm{St}+\mathrm{W})$ of scarified seed (Fig. 1). Air drying up to 240 hours did not adversely affect germination enhancement from washing $(W)$ of scarified seed. In unscarified seed, air drying was not detrimental to effects of St, W, and St $+\mathrm{W}$, although germination under these treatments was not, in some cases, significantly greater than in the untreated control.

This laboratory study demonstrated that germination enhancement obtained from stratification and wash treatments was retained by scarified seed allowed to air dry. This implies that pretreatments would not have to be applied immediately prior to planting to retain their benefit.

\section{Pretreatment Effects on Blotter Germination}

Laboratory blotter germination data included in Table 1 were transformed so that comparisons between blotter germination and field emergence could be made on a "seedlings per seeds treated" rather than a percentage basis.

Scarification alone did not enhance germination (Table 1). However, scarification appeared to facilitate effects of W, St, and $\mathrm{W}+\mathrm{St}$. Differences between $\mathrm{St}$ and $\mathrm{Sc}+\mathrm{St}$ were not significant at $P \leq 0.05$, although trends were apparent.

In the laboratory, stratification alone significantly enhanced germination over the control (Table 1). Moreover, all combination treatments which included stratification significantly enhanced germination on blotter paper. Washing alone increased germination, although this difference was not statistically significant at $P \leq 0.05$ (Table 1). The combination "scarification-wash-stratification" $(\mathrm{Sc}+\mathrm{W}+\mathrm{St})$ yielded the greatest germination. However, even with this treatment, germination was only $48.8 \%$ of the PLS treated, suggesting that the afterripening requirement was not fully met (Ansley 1983).

These results agree with other works in showing that stratification and washing (i.e. leaching) increase germination in arid shrubland Atriplex spp. (Beadle 1952, McLean 1953, Cornelius and Hylton 1969, Eddleman 1978). Scarification alone was not effective, which agrees with results of Springfield (1970) and Graves et al. (1974) in scarification tests on fourwing saltbush $[A$. canescens (Pursh) Nutt.]. Other authors have found scarification to be effective in some Atriplex spp. (Nord and Whitacre 1957, Edgar and Springfield 1977). Ansley (1983) found that germination response of Gardner saltbush seeds to scarification was related to seed source. Little research has been done on interactive effects of stratification, leaching, and scarification in Atriplex spp.

Pretreatment Effects on Field Emergence

For all treatments, germination on blotter paper was much

Table 1. Effects of seed pretreatments and planting depth on field emergence of Gardner saltbush at one irrigated site (Laramie) and two dryland reclamation sites (Thermopolis and Bridger). All seed treated was 8-10 months post-harvest.

\begin{tabular}{|c|c|c|c|c|c|c|c|}
\hline \multirow[b]{4}{*}{ Seed pretreatment ${ }^{2}$} & \multicolumn{7}{|c|}{ Average Number of Seedlings ${ }^{1}$} \\
\hline & \multirow{3}{*}{$\begin{array}{c}\text { Laboratory } \\
\text { blotter } \\
\text { germination }\end{array}$} & \multicolumn{6}{|c|}{ Planting depth } \\
\hline & & \multicolumn{2}{|c|}{ Laramie } & \multicolumn{2}{|c|}{ Thermopolis } & \multicolumn{2}{|c|}{ Bridger } \\
\hline & & $1 \mathrm{~cm}$ & $3 \mathrm{~cm}$ & $1 \mathrm{~cm}$ & $3 \mathrm{~cm}$ & $1 \mathrm{~cm}$ & $3 \mathrm{~cm}$ \\
\hline $\begin{array}{l}\text { 1. Control } \\
\text { 2. Sc }\end{array}$ & $\begin{array}{l}25 \mathrm{~d} \\
29 \mathrm{~d}\end{array}$ & $\begin{array}{l}1 \mathrm{~d}^{3} \\
3 \mathrm{~cd}\end{array}$ & $\begin{array}{l}2 \mathrm{~b} \\
2 \mathrm{~b}\end{array}$ & $\begin{array}{l}2 \mathrm{~d} \\
5 \mathrm{bcd}\end{array}$ & $\begin{array}{l}1 \mathrm{~d} \\
5 \mathrm{~b}\end{array}$ & $\begin{array}{l}0 \mathrm{a} \\
\mathrm{l} \mathrm{a}\end{array}$ & $\begin{array}{l}1 \mathrm{ab} \\
0.5 \mathrm{~b}\end{array}$ \\
\hline $\begin{array}{l}\text { 3. } W \\
\text { 4. } S c+W\end{array}$ & $\begin{array}{l}38 \mathrm{~cd} \\
58 \mathrm{~b}\end{array}$ & $\begin{array}{l}2 \mathrm{~d} \\
6 \mathrm{~cd}\end{array}$ & $\begin{array}{l}2 \mathrm{~b} \\
4 \mathrm{~b}\end{array}$ & $\begin{array}{l}3 \mathrm{~cd} \\
4 \mathrm{~cd}\end{array}$ & $\begin{array}{l}2 \mathrm{~cd} \\
4 \mathrm{~b}\end{array}$ & $\begin{array}{l}0.5 \mathrm{a} \\
0.5 \mathrm{a}\end{array}$ & $\begin{array}{l}1 \mathrm{~b} \\
2 \mathrm{ab}\end{array}$ \\
\hline $\begin{array}{l}\text { 5. } S t \\
\text { 6. } S c+S t\end{array}$ & $\begin{array}{l}50 \mathrm{bc} \\
64 \mathrm{ab}\end{array}$ & $\begin{array}{l}15 \mathrm{~b} \\
28 \mathrm{a}\end{array}$ & $\begin{array}{l}11 \mathrm{a} \\
11 \mathrm{a}\end{array}$ & $\begin{array}{l}5 \mathrm{bc} \\
9 \mathrm{a}\end{array}$ & $\begin{array}{l}5 \mathrm{~b} \\
8 \mathrm{a}\end{array}$ & $\begin{array}{l}0.5 \mathrm{a} \\
0.5 \mathrm{a}\end{array}$ & $\begin{array}{l}2 \mathrm{ab} \\
2 \mathrm{ab}\end{array}$ \\
\hline $\begin{array}{l}\text { 7. } W+S t \\
\text { 8. } S c+W+S t\end{array}$ & $\begin{array}{l}51 \mathrm{bc} \\
78 \mathrm{a}\end{array}$ & $\begin{array}{l}14 \mathrm{~b} \\
10 \mathrm{bc}\end{array}$ & $\begin{array}{l}9 \mathrm{a} \\
9 \mathrm{a}\end{array}$ & $\begin{array}{l}5 \mathrm{bcd} \\
8 \mathrm{ab}\end{array}$ & $\begin{array}{l}4 \mathrm{bc} \\
5 \mathrm{~b}\end{array}$ & $\begin{array}{r}0.5 \mathrm{a} \\
1 \mathrm{a}\end{array}$ & $\begin{array}{l}2 a b \\
4 a\end{array}$ \\
\hline
\end{tabular}

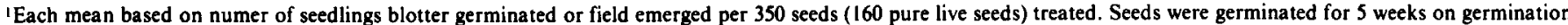

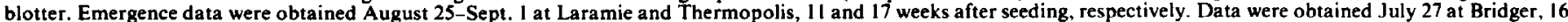
weeks after the seeds were planted.

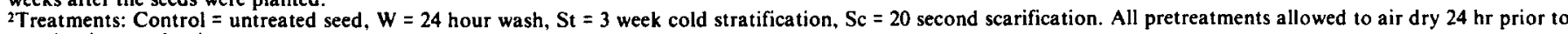
germination or planting.

${ }^{3}$ Means within each column having similar letters are not significantly different at $P \leq 0.05$ according to Duncan's new multiple range test. 
greater than emergence at any field site, including Laramie where growing conditions were least-limiting. The greatest field emergence for any treatment at any site was 28 of 160 PLS planted (Table 1), or $17.5 \%$, at Laramie. This was about one third the highest laboratory blotter germination. These results suggest that limited field establishment for this species is related to poor seedling vigor as well as to seed dormancy. Seedling vigor responses of a seed lot can be due both to the genetic makeup of the parent seed plants and to the environment prevalent at the time the seed was developing. Seedling vigor has been related to a number of morphological and/or physiological factors in various crop species (McDonald 1980) but little is known about seedling vigor of wildland shrubs. Emergence in this study was much lower than that Nord et al. (1971) reported for Gardner saltbush in California.

At the Laramie irrigated site relative responses among pretreatments were similar to laboratory results in that all pretreatments including stratification enhanced emergence for both seed depths (Table 1). Moreover, scarification appeared to facilitate stratification effects at $1-\mathrm{cm}$ seed depth but had little effect itself on emergence.

Response to washing was markedly different between field emergence at Laramie and blotter germination (Table 1). Unlike blotter germination, washing alone or with scarification had no significant effect at the Laramie site at either seed depth. Moreover, washing appeared to inhibit effects of stratification in scarified seed, in contrast to the laboratory, where $\mathbf{S c}+\mathbf{W}+\mathbf{S t}$ slightly increased germination over $\mathrm{Sc}+\mathrm{St}$. An explanation for emergence response to the wash treatments at Laramie is not readily apparent. The amount of oven-dry material lost from both unscarified and scarified seed during the 24-hour wash treatment was greater than $10 \%$ of oven-dry seed weight (Table 2). Loss of this material, which

Table 2. Effects of scarification and 24 hour wash treatments on fresh and oven dry weight of Gardner saltbush seeds.

\begin{tabular}{|c|c|c|c|}
\hline \multirow[b]{2}{*}{ Wash treatment } & \multicolumn{2}{|c|}{$\begin{array}{c}\text { Weight per Seed } \\
\text { (mg) }\end{array}$} & \multirow{2}{*}{$\begin{array}{l}\text { Percent weight } \\
\text { loss from } \\
\text { scarification }\end{array}$} \\
\hline & $\begin{array}{c}\text { Unscarified } \\
\text { seed }\end{array}$ & $\begin{array}{l}\text { Scarified } \\
\text { seed }\end{array}$ & \\
\hline \multicolumn{4}{|c|}{ Fresh Weight } \\
\hline No Wash & 2.59 & 2.16 & 16.9 \\
\hline $\begin{array}{l}\text { No Wash } \\
\text { 24-Hour Wash }\end{array}$ & $\begin{array}{l}\text { Oven-D } \\
2.46 \\
2.14\end{array}$ & ight $\begin{array}{r}2.02 \\
1.78\end{array}$ & 17.9 \\
\hline $\begin{array}{l}\text { Percent Oven Dr } \\
\text { Weight Loss }\end{array}$ & & & \\
\hline From Washing & 13.2 & 11.8 & \\
\hline
\end{tabular}

could be largely perisperm reserves, combined with $17.9 \%$ ovendry weight loss due to scarification did not inhibit blotter germination but may have been deleterious to proper field seedling development from scarified seed.

At the dryland reclamation sites emergence was much lower than at the Laramie irrigated site for both seed depths (Table 1). The greatest emergence for any treatment at Thermopolis was 9 of 160 PLS planted, or 5.6\%. Greatest emergence at Bridger was 4, or $2.5 \%$ of PLS planted. This compares to $17.5 \%$ emergence at Laramie and $48.8 \%$ germination on blotter paper. Thus, the effect of poor seedling vigor suggested by the Laramie field results was accentuated under progressively more limiting climatic/edaphic conditions at Thermopolis and Bridger.

Emergence from both seed depths was greater at Thermopolis than at Bridger even though both sites were not irrigated following seeding (Table 1 and Fig. 2). The Thermopolis site received $10 \mathrm{~cm}$ precipitation during the first 2 months following seeding while Bridger received $4 \mathrm{~cm}$ precipitation. Moreover, topsoil at Bridger was coarser textured than topsoil at Thermopolis, which might ave reduced water availability to seeds at Bridger (Ansley 1983).

At Thermopolis, relative responses among seed pretreatments generally resembled results at the Laramie site, with greatest emergence occurring in the $\mathrm{Sc}+\mathrm{St}$ treated seed at $1 \mathrm{~cm}$. Unlike Laramie washing did not inhibit effects of stratification in scarified seed at 1 $\mathrm{cm}$. There was some inhibition at $3 \mathrm{~cm}$, however.

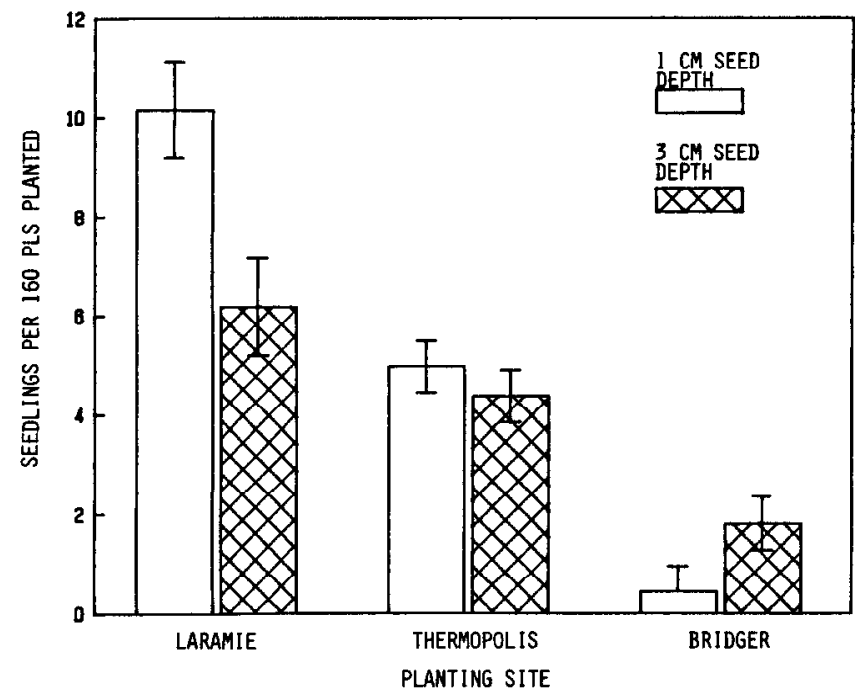

Fig. 2. Effect of planting depth on 8-10 month post-harvest Gardner saltbush seedling emergence at 3 locations averaged over all pretreatments. Bars represent the $L S D_{.05}$.

Results from Bridger were insufficient to make many conclusions about effects among pretreatments (Table 1). It appeared Sc $+W+$ St at $3 \mathrm{~cm}$ was more effective than other seed pretreatments.

\section{Effects of Seeding Depth}

Emergence, when averaged over all seed pretreatments, was significantly different between the 2 seed depths at both Laramie and Bridger (Fig. 2). At Laramie, significantly more seedlings emerged from $1 \mathrm{~cm}$ than from $3 \mathrm{~cm}$. Conversely, at Bridger, significantly more seedlings emerged from $3 \mathrm{~cm}$ than $1 \mathrm{~cm}$. Thermopolis had no real difference in emergence between the 2 seed depths. It was difficult to prepare a smooth seedbed at Thermopolis due to the silty/clayey topsoil texture (Ansley 1983). The uneven, often cloddy surface may have precluded accurate regulation of planting depth at this site. Seedbeds were smooth at both Laramie and Bridger at the time of seeding.

Results from this study suggest that Gardner saltbush emergence is greater from $1-\mathrm{cm}$ than $3-\mathrm{cm}$ planting depth when soil moisture is adequate. However, on extremely arid sites, such as Bridger, dryland seeding may be more successful if seeds are planted deeper than $1 \mathrm{~cm}$. These results agree with Nord et al. (1971), who found that Gardner saltbush emergence was greater from $1.3 \mathrm{~cm}$ than 2.5 $\mathrm{cm}$ when seeds were planted in February and March. At an April planting date, emergence from $1.3 \mathrm{~cm}$ decreased from that obtained by the earlier planting date, while emergence from $2.5 \mathrm{~cm}$ remained unchanged. Soil moisture availability may have decreased more at $1.3 \mathrm{~cm}$ than $2.5 \mathrm{~cm}$ soil depth from February to April.

\section{Conclusions}

Seed pretreatments used in this study enhanced both laboratory blotter germination and field emergence of Gardner saltbush seeds. However, even under relatively nonlimiting growing conditions, field emergence was much lower than laboratory blotter germination, indicating that this species has poor seedling vigor in addition to seed dormancy. Moreover, when compared to the untreated control, relative response to seed pretreatments often differed between germination on blotter paper and field emergence studies.

Spring-seeding artificially stratified Gardner saltbush seeds was 
successful. Although emergence of stratified seeds was low relative to total PLS planted, it was substantial relative to untreated controls at both Laramie and Thermopolis.

Previously recommended planting depth for Gardner saltbush is $1.3 \mathrm{~cm}$ (Vories 1981). McLean (1953) found emergence of Nuttall saltbush declined rapidly when seeds were planted below $1.3 \mathrm{~cm}$. We found that emergence was significantly greater from $1 \mathrm{~cm}$ than $3 \mathrm{~cm}$ when moisture was adequate. However, deeper planting depths may have merit on extremely arid sites.

\section{Literature Cited}

Ansley, R. James. 1983. Dormancy, germination, emergence and ecology of Gardner saltbush [Atriplex gardneri (Moq.) D. Dietr.] seeds. Ph.D. Diss., Univ. Wyoming, Laramie.

Ansley, R. James, and R.H. Abernethy. 1982. Seed dormancy and germination enhancement of Gardner saltbush (Atriplex gardneri). Abstr. p. 23. In: Proc. Soc. Range Manage. 35th Ann. Meeting, Calgary, Alberta.

Beadle, N.C.W.1952. Studies in halophytes. 1. The germination of the seed and establishment of the seedlings of five species of Atriplex in Australia. Ecology 33:49-62.

Becker, C.F., and J.D. Alyea. 1964. Temperature probabilities in Wyoming. Univ. Wyo. Agr. Sta. Bull. 415.

Bleak, A.T., N.C. Frischknecht, A.P. Plummer, and R.E. Eckert, Jr. 1965. Problems in artificial and natural revegetation of the arid shadscale vegetation zone of Utah and Nevada. J. Range Manage. 18:59-63.

Cornelius, D.R., and L.O. Hylton. 1969. Influence of temperature and leachate on germination of Atriplex polycarpa. Agron. J. 61:209-211.

DePuit, E.J., and J.G. Coenenberg. 1980. Establishment of diverse native plant communities on coal surface-mined lands in Montana as influenced by seeding method, mixture and rate. Mont. Agr. Exp. Sta. Res. Pap. 163. Montana State Univ., Bozeman.

Eddleman, L.E. 1978. Survey of viability of indigenous grasses, forbs and shrubs. Annu. Prog. Rep. prepared for US Energy Res. and Develop. Admin.

Edgar, R.L., and H.W. Springfield. 1977. Germination characteristics of Broadscale: a possible saline-alkaline site stabilizer. J. Range Manage. 30:296-299.

Foiles, M.W. 1974. Atriplex L., Saltbush. p. 240-243. In: Seeds of woody plants in the U.S. USDA Agr. Handb. 450, Washington, D.C.

Grabe, Don F. 1970. Tetrazolium testing handbook for agricultural seeds. Contrib. No. 29 to Handbook on Seed Testing. Ass. Off. Seed. Anal., Corvallis, Ore.

Graves, W., B.L. Kay, and W.A. Williams. 1974. Seed-treatment studies of seven Mohave Desert shrub species. In: Test of seeds of Mohave Desert shrubs. Prog. Rep., Dep. Agron. and Range Sci., Univ. Calif., Davis. Mimeo.

McDonald, M.B. Jr. 1980. Assessment of seed quality. Hort. Sci. 15:784-788.
McDonough, W.T. 1970. Germination of 21 specics collected from a high-elevation rangeland in Utah. Amer. Midl. Natur. 4:551-554.

McKell, C.M. 1979. Selection, propagation and field establishment of native plant species on disturbed arid lands. Utah Agric. Exp. Sta. Bull. 500, Utah State Univ., Logan.

McLean, A. 1953. The autecology of Atriplex nuttallii S. Wats. in southwestern Saskatchewan. M.S. thesis. Utah State Agr. Coll., Logan.

Nord, E.C., and J.E. Whitacre. 1957. Germination of fourwing saltbush improved by scarification and grading. USDA Forest Serv., Calif. Forest and Range Exp. Sta. Res. Note. 125.

Nord, E.C., P.F. Hartless, and W.D. Nettleton. 1971. Effects of several factors on saltbush establishment in California. J. Range Manage. 24:216-223

Osmond, C.B., O. Bjorkman, and D.J. Anderson. 1980. Physiological processes in plant ecology-toward a synthesis with Atriplex. SpringerVerlag, New York.

Plummer, A. Perry. 1976. Shrubs for the subalpine zone of the Wasatch Plateau. p. 33-40. In: Proc. High Altitude Revegetation Workshop No. 2. R.H. Zuck and L.F. Brown (eds.). Colorado State Univ., Fort Collins.

Sabo, D.G., G.V. Johnson, W.C. Martin, and E.F. Aldon. 1979. Germination requirements of 19 species of arid land plants. USDA Forest Serv. Res. Pap. RM-210. USDA Forest Serv., Rocky Mt. Forest and Range Exp. Sta., Fort Collins, Colo.

Sindelar, B.W., R. Atkinson, M. Majerus, and K. Proctor. 1974. Surface mined land reclamation research at Colstrip Montana. Montana Agr. Exp. Sta. Res. Rep. 69. Bozeman.

Springfield, H.W. 1970. Germination and establishment of fourwing saltbush in the Southwest. USDA Forest Serv. Res. Pap. RM-55. Rocky Mountain Forest Range Exp. Sta. Fort. Collins, Colo.

Stubbendieck, J., S.L. Hatch, and K.J. Kjar. 1981. North American Range Plants. Nat. Resources Enterprises, Inc., Lincoln, Neb.

Vories, K. 1981. Growing Colorado plants from seed: a state of the art. Vol. I: Shrubs. USDA Forest Serv. Gen. Tech. Rep. INT-103. Intermtn. Forest and Range Exp. Sta., Ogden, Utah.

Weber, G.P., and L.E. Wiesner. 1980. Tetrazolium testing procedures for native shrubs and forbs. J. Seed Tech. 5:23-24.

Wood, M.K., R.W. Knight, and J.A. Young. 1976. Spiny hopsage germination. J. Range Manage. 29:53-56.

Young, J.A., and R.A. Evans. 1981. Germination of seeds of antelope bitterbrush, desert bitterbrush, and cliff rose. USDA Science and Educ. Admin. ARR W-17.

Young, J.A., B.L. Kay, H. George, and R.A. Evans. 1980. Germination of three species of Atriplex. Agron. J. 72:705-709.

Young, J.A., R.A. Evans, R. Stevens, and R.L. Everett. 1981. Germination of Kochia prostrata seed. Agron. J. 73:957-96I.

Young, J.A., R.A. Evans, B.L. Kay, R.E. Owen, and F.L. Jurak. 1978. Collecting, processing, and germinating seeds of western wildland plants. USDA Science and Educ. Admin. Agr. Rev. and Manuals. ARM-W-3. 